\title{
A Better Flight Path: How Ottawa can Cash In on Airports and Benefit Travellers
}

\author{
by \\ Steven Robins
}

- Canada is the only country in the world in which the largest airports are operated by non-profit, non-share capital airport authorities, with the federal government owning and leasing land to the airport authorities.

- These leases represent an equity value that the federal government can unlock to finance other socially important infrastructure. Ottawa could raise between $\$ 7.2$ billion and $\$ 16.6$ billion for infrastructure investment by selling equity in the airports.

- Most importantly, selling equity can improve the airport experience for travellers by creating more opportunities for services at airports and removing the onerous airport rent that leads to higher costs for travellers. However, the government must have in place the appropriate regulatory and transaction policies to ensure that travellers are put first by any private owners of airports.

The federal government is currently exploring "asset recycling" of its airports; i.e., selling equity stakes to attract institutional investment and fund new infrastructure (Curry 2016). Selling equity stakes in airports could, according to my analysis, raise $\$ 7.2$ billion to $\$ 16.6$ billion for infrastructure investment, after accounting for debt repayment. There is significant uncertainty in the value, stemming from legal questions regarding outstanding airport debt that should be resolved prior to any transaction. Changes to an airport's ownership structure would also address issues with the current lease structure. However, to ensure asset recycling produces positive

The author thanks Benjamin Dachis, Colleen Campbell, Akash Deep, John Macomber and several anonymous reviewers for advice and helpful comments on an earlier draft. The author retains responsibility for any errors and the views expressed here. 
outcomes for Canadians, decision-makers must pay close attention to the details. This E-Brief provides a roadmap for government to unlock the value of federally owned airports in a way that maximizes the public interest.

Selling equity stakes would not change the incentives airport operators face from competition from other airports and modes of travel. Air travellers are highly price sensitive, according to the International Air Transport Association (Smyth and Pearce 2008). This means that an airport that seeks to maximize revenues needs to boost its value proposition through improved quality or lower prices. Airports have limited ability to raise prices without losing customers. Any new airport operator would face the same situation. This aligns with economic development objectives, since both airports and the local economy benefit when travel volume increases.

I focus in this E-Brief on Canada's eight largest airports, which are operated by local airport authorities on long-term leases from the federal government (Emerson 2015a) and represent 81 percent of 2015 passenger volumes (Government of Canada 2016). The other 14 National Airport System (NAS) airports that have the same operating model face similar challenges and would benefit from the same analysis. Meanwhile, the operating models of Canada's other more than 100 small airports (Figure 1) face different issues and could not raise meaningful funds for new investments due to their smaller scale and are, therefore, beyond the scope of this study.

\section{The Need for Change}

Some stakeholders, such as some airport authority management and airlines, have claimed that involving private investors would mean higher costs for travelers (Rovinescu 2016, Laroche and Richmond 2016). However, this is not necessarily true. Canada's airports generate nearly $\$ 2$ billion annually in cash flows, a portion of which would provide returns to investors, without increasing costs to travellers.

There are four issues with the current NAS airport operating model stemming from its lease structure, along with the airport authorities' corporate structure, that result in higher costs for travellers. First, Transport Canada charges a progressive ground rent to airport authorities of up to 12 percent of revenues. This formula, as opposed to a tax on profits, creates a disincentive for airport authorities to invest in low-margin business opportunities such as retail and other services to travellers that might otherwise be profitable and defray costs that travellers would otherwise need to pay (Dachis 2014). As a result, airports tend not to pursue some economically beneficial projects (See Box 1).

Second, leases are for 60 years, with potential extension for 20 years. Most current leases expire in the 2070s. On expiry, the airports must be returned to government "in good condition and free of debt (Aeroports de Montreal 2015)." Airports frequently issue 30-year or longer debt to finance long-term infrastructure improvements (Dachis 2014). As the end of their leases approach, airports will be required to amortize investments over shorter time horizons, resulting in higher debt costs and less investment as they rush to repay principal to eliminate debt.

Third, the airport authorities are non-share, non-profit corporations. ${ }^{1}$ Therefore, they are unable to issue equity, relying solely on retained earnings and debt financing. But debt markets are unwilling to finance 100 percent of an investment (Tretheway and Markhvida 2013). This results in a need to save airport improvement fees to generate retained earnings to finance a project such as a terminal expansion, thus delaying such potentially worthwhile initiatives.

1 Calgary and Edmonton airport authorities are non-profit corporations under Alberta law, while the remainder are incorporated federally under the Canada Not-for-profit Corporations Act. 


\section{Figure 1: Ownership of Canada's Airports}

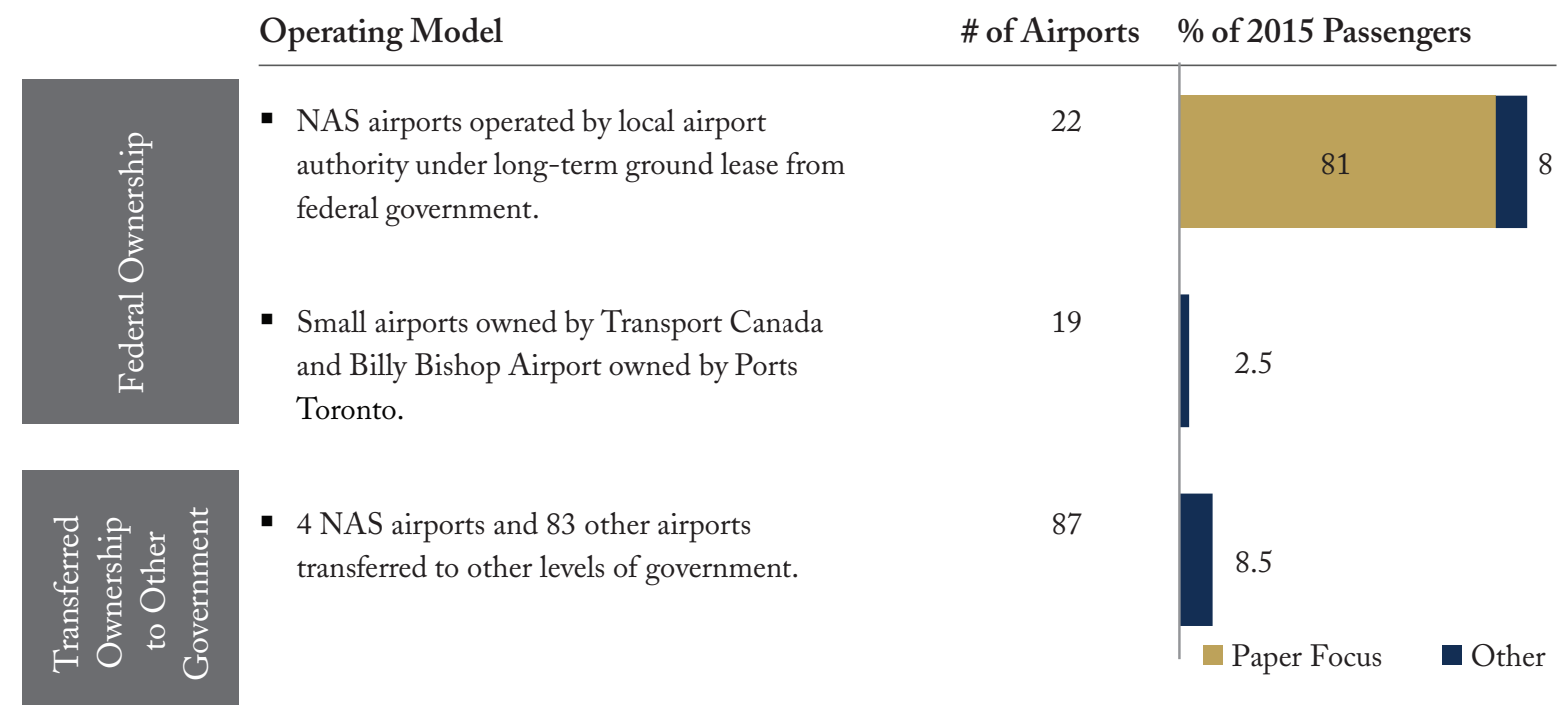

Source: Author's calculations from Statistics Canada, CANSIM, series 401-004 Air Traffic Passengers and Flights; Canada Transportation Act Review; Ports Toronto; and Transport Canada data.

\section{Box 1: The Problem with Airport Rent}

Consider an airport expansion project - adding space for a new restaurant. All numbers illustrative.

\begin{tabular}{lcc} 
& Status Quo & $\begin{array}{c}\text { Traditional } \\
\text { Corporate }\end{array}$ \\
\cline { 2 - 2 } Rental Revenue & 100 & 100 \\
\hline Ground Rent to Federal Government & -12 & 0 \\
\hline Operating Cost & -85 & -85 \\
\hline Income Before Taxes & 3 & 15 \\
\hline Taxes & 0 & -5 \\
\hline Income & 3 & $\mathbf{1 0}$ \\
\hline Capital Investment & 100 & 100 \\
\hline Return on Investment & $3 \%$ & $10 \%$ \\
\hline
\end{tabular}

An airport under the status quo would not choose to invest in such an expansion because the projected return might be lower than its cost of finance - even though the project has positive overall economic and financial returns, both to the airport and to government. 
Finally, airport infrastructure is fully funded on a user-fee basis. Former federal transport minister David Emerson's review of transportation policy found unanimity among airlines, airport, provinces and many other stakeholders calling for lower airport fees (e.g., through subsidies) (Emerson 2015a). However, these stakeholders have a strong interest in growing air traffic volumes, and government should seriously review the rationale for public subsidy. This E-Brief argues for asset recycling while maintaining the user-fee policy.

\section{What Canadians Own}

The non-share, non-profit ownership model of Canada's airports is unique globally. Beginning in 1992, the federal government leased airport lands and existing assets to newly created airport authorities. These authorities took on responsibility for financing operating expenses and new capital investment through user fees. There has been no taxpayer financing of these expenses since, nor does the federal government maintain majority control of the airport authority boards, which are composed of representatives of all three levels of government and the community. However, it remains the residual owner since the airports will be handed back at the end of the lease terms.

This arrangement means Canada's airports have significant untapped potential equity value, and the federal government should find a way to unlock it.

The eight largest airport authorities likely represent more than 90 percent of potential equity value, given the passenger volumes of smaller NAS airports and previous divestitures by the federal government to provinces and municipalities of even smaller airports. As non-share corporations, they are unable to issue equity to finance investment. Any equity-sale scenario would require the replacement or conversion of these authorities to traditional share-capital corporations, with the federal government initially owning 100 percent of the equity and then selling all or a portion of it to a private-sector investor. These choices do not affect the projected total equity value of the airports.

Publicly traded airports and recent airport sales in Europe, Australia and New Zealand provide an indication of how institutional investors would likely value the largest Canadian airports (see Box 2 for a detailed methodology). This analysis values the airports at their current revenue and earnings levels - it does not contemplate raising fees to provide a return on investment. Rather, investors would receive their returns from the airports' existing cash flows. Based on this methodology and analysis, the federal government's equity stake in these airports would likely be worth between $\$ 7.2$ billion and $\$ 16.6$ billion, which could be recycled to other infrastructure projects, net of the retirement of existing airport debt. ${ }^{2}$ Toronto Pearson, Vancouver and Montreal airports represent more than 80 percent of the potential equity value (See Table 1).

This five-step analysis values the total equity. Therefore, if the government maintained a financial interest through retaining equity or any other income stream, the upfront payment would be reduced. However, a phased

* 2 A legal opinion provided to Aéroports de Montréal indicates that an equity sale of the Montreal airport is unlikely to be considered a continuation of "corporate existence (Aéroports de Montréal 2015)." Therefore, such a sale would require the consent of bondholders or the repayment of existing debt. The repayment price is determined by a makewhole formula defined when the debt is issued - usually based on the current yield of federal government debt of similar maturities. This price is typically at a premium - the debt-call premium - to the existing market value of debt. The situation is likely similar at other airports. There is the possibility this payment could be avoided through the transaction structure, pending legal analysis. 


\section{Box 2: Financial Valuation Methodology}

I used a standard five-step methodology to establish indicative values for these airports:

1. Calculated Earnings Before Interest, Taxes, Depreciation (EBITDA), a common metric used as a proxy for free cash flow in airport valuation, based on 2015 financials for each airport.

2. Adjusted EBITDA to eliminate ground rent at each airport, on the assumption that the federal government would eliminate these charges.

3. Calculated the ratio of total enterprise value (TEV) - debt and equity - to EBITDA for a set of nine publicly traded airports and 23 airports sold since 2011 in Western Europe, Australia and New Zealand. The ratios ranged from 8x to 23x. There was a distinct upward trend in transaction multiples since 2011, suggesting the analysis may be conservative.

4. Established a valuation range of $13 \mathrm{x}$ to $17 \mathrm{x}$ TEV/EBITDA, based on data-set medians of $14 \mathrm{x}$ to $15 \mathrm{x}$, depending on date range for historical transactions and distribution of data points. This range includes the $30^{\text {th }}$ percentile to $60^{\text {th }}$ percentile of trading and comparable transactions since 2014 and the $35^{\text {th }}$ percentile to $80^{\text {th }}$ percentile of all trading and comparable transactions.

5. Applied multiples to the adjusted EBITDA of each of the airports to estimate total enterprise value and then subtracted net debt (market value of debt less unrestricted cash and cash restricted by debt covenants). I also subtracted the debt-call premium, ${ }^{*}$ which may be paid to bondholders in some transaction scenarios from the low end of the range but not to the high end.

The estimated revenue and EBITDA growth rates of these airports, as well as the investor's perceived risk will significantly influence the EBITDA multiple an investor is willing to pay. Both these variables have significant uncertainty. Critical government decisions regarding transaction structure (e.g., regulatory framework, statutory requirements) will affect the sale value. Airports in similar economies are likely to have similar growth rates and risks. A detailed market sounding with institutional investors - like that currently being conducted by Credit Suisse for the Canada Development Investment Corporation, which manages investments on behalf of the federal governments and sells them to the broader public when appropriate - would be required to better estimate likely equity value. I rounded equity values to account for the uncertainties involved in the final estimates.

* See footnote 2 .

equity sale would allow the government to share in the increased value from improvements made by the buyer after any sale. (The potential for efficiency improvements is not included in the analysis.)

In addition to the upfront value of equity, the airport authorities would become corporate taxpayers to both federal and provincial governments. Forecasting corporate tax payments is difficult because the privately operated airports make widely varying decisions around borrowing and capital investment, both of which create tax deductions. ${ }^{3}$ In the most conservative tax-revenue scenario, the new airport structures could borrow to the

3 In addition, the new buyer may be able to deduct from its taxable income the amortization of the premium paid over book value - reducing the tax burden owing in the years immediately following the transaction. This impact is beyond the scope of this analysis. 


\begin{tabular}{|c|c|c|c|c|}
\hline Airport & $\begin{array}{l}2015 \text { Adjusted } \\
\text { EBITDA } \\
\text { (\$M) }\end{array}$ & $\begin{array}{l}\text { Net Debt at } \\
\text { Market Value } \\
\text { (\$M) }\end{array}$ & $\begin{array}{l}\text { Debt Call } \\
\text { Premium } \\
\text { (\$M) }\end{array}$ & Estimated Equity Value \\
\hline Toronto Pearson & 789 & 7,456 & 830 & $\$ 2$ billion - $\$ 6$ billion \\
\hline Vancouver & 300 & 510 & 64 & $\$ 3.2$ billion - $\$ 4.5$ billion \\
\hline Montreal & 292 & 2,206 & 386 & $\$ 1.3$ billion - $\$ 2.9$ billion \\
\hline Calgary & 259 & 3,197 & - & $\$ 150$ million - $\$ 1.2$ billion \\
\hline Edmonton & 121 & 1,095 & 64 & $\$ 400$ million - $\$ 1$ billion \\
\hline Halifax & 61 & 659 & 111 & $\$ 100$ million - $\$ 400$ million \\
\hline Winnipeg & 44 & 348 & 107 & $\$ 0-\$ 350$ million \\
\hline Ottawa & 61 & 662 & 125 & $\$ 0-\$ 400$ million \\
\hline Total & 1,925 & 16,134 & 1,687 & $\$ 7.2 \mathrm{~B}-\$ 16.6 \mathrm{~B}$ \\
\hline \multicolumn{5}{|c|}{$\begin{array}{l}\text { Source: Author's analysis of S\&P Capital IQData and Airport } 2015 \text { Financial Statements for Adjusted EBITDA, Author's } \\
\text { analysis of Bloomberg Data for market value and debt call premium as at November 8, 2016. Note: Calgary and Edmonton } \\
\text { airports have outstanding borrowings from the Alberta Capital Finance Authority, an Alberta Government authority. This } \\
\text { debt is not publicly traded. I valued this debt using the Authority's early repayment formula, which accounts for the debt-call } \\
\text { premium. }\end{array}$} \\
\hline
\end{tabular}

same extent as Sydney airport, the publicly traded airport whose interest payments total 40 percent of EBITDA (SEP Capital IQ 2016).

The equivalent arrangement in Canada would result in average annual federal tax of about $\$ 60$ million and provincial tax of about $\$ 50$ million in the long run, insufficient to fully replace the current ground rent (Figure 2). As well, airports currently make payments-in-lieu of taxes (PILT) to municipalities, which would be replaced by property taxes in the event of asset recycling. Should these property taxes increase above the current PILT, which is uncertain, this would reduce the airports' equity value to the federal government, but transfer that value to municipalities. Additional property tax revenue for municipalities could address their infrastructure investment backlogs. The uncertainty over the future level of property taxes should be resolved prior to any sale.

\section{How to Involve Institutional Capital Successfully}

If Ottawa elects to sell equity stakes in airports, it should first make policy decisions in four areas:

- The operating model of the airports, including what the new airport entities will own and what share is sold to institutional investors;

- The transaction process that will best maximize financial value to the government;

- The regulatory policy that will ensure continued positive outcomes for Canadians; and

- The continuation of the current user-pay policy, determining which expenses, if any, will be borne by taxpayers. 


\section{Figure 2: Indicative Implications for Government Revenue}

Pro-forma Financial (8 Largest Airports)

\$Millions

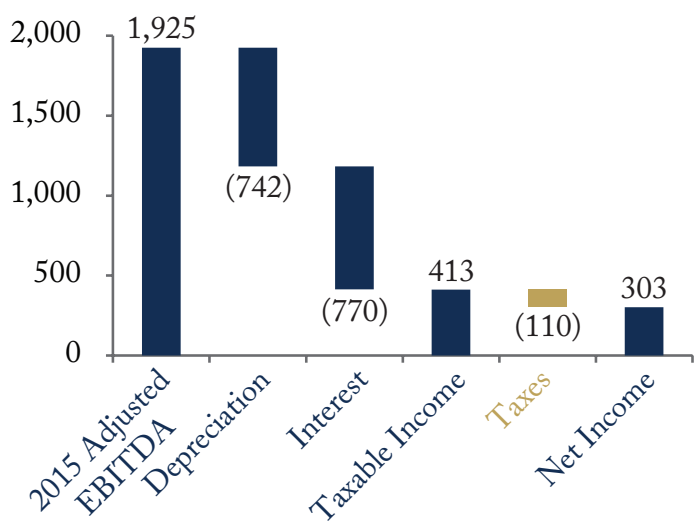

Ongoing Government Revenues

\$Millions

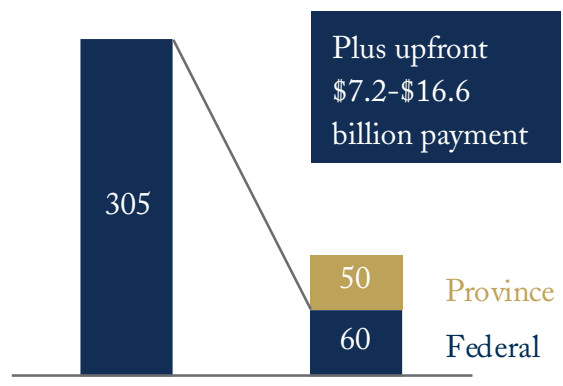

Current

Post-Transaction

Source: Author's analysis of S\&P Capital IQ and Airport 2015 financial statements.

These recommendations are based on a review of policy decisions made in the UK, Australia and New Zealand that sold partial or full equity stakes to institutional investors. These countries have converted their airport ownership into corporate entities with equity capital and sold equity to institutional investors through both private sales and public offerings. Two of them - the UK and Australia - have pricing regulations and restrictions on owning multiple airports to prevent abuse of market power (Table 2).

\section{Operating Model}

For its part, Emerson's thorough review recommended transforming the airport authorities into share-capital corporations and then selling all or part of the equity to institutional investors (Emerson 2015b). He also considered a range of equity-sale alternatives that contemplated dissolving the existing airport authorities (Emerson 2015a). The result would be the same: a traditional corporate structure owning the land, assets and managing the operations, funded by debt and equity, with a portion or all the equity owned by private investors.

Converting airport authorities into federally owned share-capital corporations would be difficult without the airport authorities' cooperation. The federal government could instead sell its interest in the ground leases to a private investor, leaving it to negotiate with the airport authorities. While there is a wide range of potential approaches to unlocking this value, all require navigating the existing legal framework between airport authorities and the federal government.

After creating share-capital corporations, the government can then choose to receive the value of its equity in an upfront payment or as dividends. It should determine its target ownership percentage based on the desired mix of upfront and ongoing income. However, if the government wants an airport to be operated independently, it should signal that intention by selling a majority stake, as identified in market soundings leading up to Ontario's Hydro One sale (Ontario 2015). 


\begin{tabular}{|c|c|c|c|}
\hline & U.K. & Australia & New Zealand \\
\hline Ownership & $\begin{array}{l}\text { Initially a single publicly- } \\
\text { traded entity for all airports, } \\
\text { taken private in } 2006 \text { and } \\
\text { then separated by competition } \\
\text { regulator. }\end{array}$ & $\begin{array}{l}3 \text { major airports owned by } \\
\text { institutional investors, Sydney } \\
\text { airport is publicly traded. A } \\
\text { single investor cannot own } \\
\text { multiple airports. }\end{array}$ & $\begin{array}{l}\text { Mostly majority-owned } \\
\text { by public and private } \\
\text { investors - local governments } \\
\text { maintain stakes, and national } \\
\text { government has limited stakes. }\end{array}$ \\
\hline Operating Model & $\begin{array}{l}\text { Airports own land and own } \\
\text { and operate assets but cannot } \\
\text { sell land for other purposes. }\end{array}$ & $\begin{array}{l}\text { Airports lease land and assets } \\
\text { from government on } 99 \text { year } \\
\text { lease. Lease paid upfront so as } \\
\text { to avoid ground rent issues in } \\
\text { Canada. }\end{array}$ & $\begin{array}{l}\text { Airports own land and own } \\
\text { and operate assets and can sell } \\
\text { for other purposes. }\end{array}$ \\
\hline Transaction Process & $\begin{array}{l}\text { All major Airports sold } \\
\text { through } 1988 \text { IPO. }\end{array}$ & $\begin{array}{l}\text { All airports privatized through } \\
\text { sale to institutional investors } \\
\text { from } 1997-2002-\text { Sydney } \\
\text { airport later IPO'd by owner. }\end{array}$ & $\begin{array}{l}\text { All airports corporatized } \\
\text { in 1980s. Auckland airport } \\
\text { IPO'd in 1998, with other } \\
\text { airports sold through private } \\
\text { placement. }\end{array}$ \\
\hline Regulatory Policy & $\begin{array}{l}\text { Price-cap regulation at } \\
\text { Heathrow and Gatwick; } \\
\text { other airports evaluated for } \\
\text { market power supplemented } \\
\text { by Competition Commission } \\
\text { restrictions on market power } \\
\text { resulting from owning } \\
\text { multiple competitive airports } \\
\text { since } 2009 \text {. }\end{array}$ & $\begin{array}{l}\text { Price-monitoring regulation } \\
\text { with no investor owning } \\
\text { multiple airports. }\end{array}$ & No price-setting regulation. \\
\hline
\end{tabular}

\section{Transaction Process}

The goal of any airport sale transaction process should be to maximize the value received by taxpayers for their stake. As a first step, the government should solicit interest from potential domestic and international investors. Canadian pension plans currently own airports throughout Europe, purchased in competition against international bidders. The federal government could accomplish this through an IPO or a competitive public auction to private institutional investors to address any public perception that the government might not receive a fair price. In general, the larger airports may be best suited for an IPO, while smaller ones could be auctioned to institutional investors.

Further, for the largest airports, a staged sale may be necessary to account for the capacity of the investor market. Hydro One market sounding suggested a $\$ 3$ billion public market appetite for of Hydro One shares at any given time (Ontario 2015), while Canada Pension Plan Investment Board CEO Mark Machin indicated that the pension fund was interested in investment opportunities above $\$ 500$ million. This provides a general guide to the minimum transaction size necessary to attract institutional investment. A staged sale also allows for the government to capture some appreciation from improvements made by the new operator. The final transaction process should be determined by government after a detailed market sounding of potential investors. 


\section{Regulatory Policy}

Institutional-investor-owned airports may act like monopolies and, therefore, require some price regulation. However, their market power is checked by competition with other airports - particularly for hub airports - and other travel modes, reducing the required regulatory strictness. Still, the government should prevent investors from owning multiple airports that compete directly - either in the local market, or as hubs - as in Australia and the United Kingdom.

Furthermore, the government should adopt price-monitoring regulation based on the Australian system, with the ability to impose price caps if it is found that airports are abusing market power. A 2011 Australian review recommended the continuation of this system. Evidence from Bilotkach et al. (2012) supports price monitoring, as the study found that EU airports under price-monitoring regimes had lower aeronautical charges than those under regulatory structures. The other commonly used structure - price-cap regulation - does not efficiently allocate scarce landing slots because the artificially low price of using runway space has led to congestion at London-area airports (Dachis 2014).

There is also the potential for vertical integration between airlines and airports that could exclude new entrants. However, the federal government can rely on the Competition Bureau to regulate abuse of market power (Dachis 2014).

After selling equity stakes, the government will still have an ongoing public interest in maintaining continued use of airport lands as airports, given the extensive restrictions on new airports entering the market. This can be achieved through an encumbrance on the land title or conditions in the sale agreement.

\section{User-Pay Principle}

Aviation stakeholders have long advocated for a reduction in fees and taxes. Indeed, the Emerson report found that "Canada was unique among its competitors in charging onerous rents and taxes that undermine competitiveness (Emerson 2015b)," as it requires full user-pay for airport infrastructure, security and navigation services. Many stakeholders point to a need to compete with government-funded US airports that may be luring travellers from Canadian operations (Gill 2012). Government subsidies are justified where there are positive externalities - when broader society benefits from an individual's decision and, absent a subsidy, the individual wouldn't make the same decision. However, air travellers receive most of the benefits from air travel, so there is not a clear rationale for public subsidy. The government should seek to continue the user-pay policy for airport infrastructure.

\section{Security}

This E-Brief assumes that the Canadian Air Transport Security Authority - the Crown Corporation responsible for airport security - is left unchanged, meaning that airport security is maintained in public hands in the event of a sale.

\section{Conclusion}

The federal government has between $\$ 7.2$ billion and $\$ 16.6$ billion invested as equity in our eight largest airports, but this equity does not show up on Ottawa's balance sheet. The government should sell equity in these airports with the proceeds recycled to fund new investments in other infrastructure. These transactions are likely to be in the public interest if decision-makers get the transaction and policy details right. 


\section{References}

Aéroports de Montréal. 2015. The Canadian Airport Model at the Crossroads. Available at: https://www. tc.gc.ca/eng/ctareview2014/pdf/Aeroports_de_Montreal_Submission_Engl.pdf.

Australia. 2011. Economic Regulation of Airport Services. Productivity Commission. Available at: http://www. pc.gov.au/inquiries/completed/airport-regulation/report/airport-regulation.pdf.

Bilotkach, Volodymyr, et al. 2012. "Regulation, Privatization, and Airport Charges: Panel Data Evidence from European Airports.” Journal of Regulatory Economics 42 (1): 73-94. doi:10.1007/s11149-0119172-1.

Bloomberg. 2016. Data Series

Calgary Airport Authority. 2015.2015 Annual Report.

Coombs, Tim. 2016. "Airport Transaction Update and 2016 Outlook." February 2. Available at: http:// www.rdcaviation.com/Insights/Article/44/Airport-Transaction-Update-and-2016-Outlook.

Curry, Bill. 2016. "Liberals Ask Credit Suisse to Study Benefits of Privatizing Airports." The Globe and Mail. Accessed October 24. http://www.theglobeandmail.com/news/politics/liberals-asks-creditsuisse-to-study-benefits-of-privatizing-airports/article32450487/.

Dachis, Benjamin. 2014. Full Throttle: Reforming Canada's Aviation Policy. Commentary 398. Toronto: C.D. Howe Institute. January. Available at: https://cdhowe.org/sites/default/files/attachments/ research_papers/mixed/Commentary_398_0.pdf.

Edmonton Regional Airports Authority. 2015.2015 Annual Report and Financials.

Emerson, David. 2015a. Pathways: Connecting Canada's Transportation System to the World-Appendicies. Canada Transportation Act Review. Available at: http://www.tc.gc.ca/eng/ctareview2014/CTAR_ Vol2_EN.pdf.

2015b. Pathways: Connecting Canada's Transportation System to the World-Volume 1. Canada Transportation Act Review.

Gill, Vijay. 2012. Driven Away: Why More Canadians Are Choosing Cross Border Airports. Conference Board of Canada. Available at: http://www.cacairports.ca/sites/default/files/Driven\%20Away\%20-\%20 Why\%20More\%20Canadians\%20are\%20Choosing\%20Border\%20Airports\%20-\%20FINAL.pdf.

Government of Alberta. 2016. Standing Policies Manual of the Alberta Capital Finance Authority. . 2016. "Alberta Capital Finance Authority - Interest Rates.” Accessed November 8. Available at: http://www.acfa.gov.ab.ca/nav/rates.html.

Government of Canada, Statistics Canada. 2016. "CANSIM - 401-0044 - Air Passenger Traffic and Flights.” June 3. Available at: http://www5.statcan.gc.ca/cansim/a26?lang=eng\&retrLang=eng\&id=40 10044\&pattern=401-0044\%2C 401-0045\&tabMode=dataTable\&srchLan=-1\&p1=-1\&p2=-1.

Greater Toronto Airports Authority. 2015. Management's Discussion and Analysis and Financial Statements. Halifax International Airports Authority. 2015. HLAA 2015 Annual Report.

Kuyucak, Ferhan, and Bijan Vasigh. 2011. "Privatization and Regulation: A Review of Airport Industry Practices.”June. Available at: https://www.researchgate.net/publication/303999729_Privatization_ and_Regulation_A_Review_of_Airport_Industry_Practices 
Laroche, Mark, and Craig Richmond. 2016. "Travellers will pay the price if Canada's airports are sold.” The Globe and Mail. October 24.Available at: http://www.theglobeandmail.com/report-on-business/ rob-commentary/travellers-will-pay-the-price-if-canadas-airports-are-sold/article32485207/

Nelson, Jacqueline. 2016. "CPPIB Head Cautious on Canadian Infrastructure." The Globe and Mail.

November 1. Available at: http://www.theglobeandmail.com/report-on-business/cppib-headcautious-on-canadian-infrastructure/article32617837/.

Ontario, Government of. 2015. "Improving Performance and Unlocking Value in the Electricity Sector." Text. Ontario.ca. December 10. Available at: https://www.ontario.ca/page/improving-performanceand-unlocking-value-electricity-sector.

Ottawa International Airport Authority. 2015. 2015 Annual Report.

PortsToronto. 2016. “Airport | PortsToronto.” Accessed November 2. Available at: https://www. portstoronto.com/airport.aspx.

Rovinescu, Calin. 2016. "The trouble with Canadian airport privatization.” The Globe and Mail. December 19. Available at: http://www.theglobeandmail.com/report-on-business/rob-commentary/the-modelis-not-broken-only-dented-the-trouble-with-canadian-airport-privatization/article33359029/

Smyth, Mark, and Brian Pearce. 2008. "Air Travel Demand.” LATA Economics Briefing, no. 9(April).

S\&P Capital IQ. 2016.Data Series.

Transport Canada. 2016. “Airport Divestiture Status Report - Transport Canada.” March 24. Available at: http://web.archive.org/web/20160324221600/http://www.tc.gc.ca/eng/programs/airports-statusmenu-441.htm.

Tretheway, Mike. 2001. “Airport Ownership, Management and Price Regulation.” InterVISTAS Consulting.

Tretheway, Mike, and Kate Markhvida. 2013. "Airports in the Aviation Value Chain: Financing, Returns, Risk and Investment." Discussion Paper presented at the International Transport Forum. Available at: http://www.oecd-ilibrary.org/docserver/download/5k46bj4f2p26.pdf?expires=1478137048\&id=id\&ac cname=guest\&checksum=FC9D7E46476CC1F5D10B0AC031584F84.

Vancouver Airport Authority. 2015. YVR Connects: 2015 Sustainability Report.

Winnipeg Airports Authority. 2015. 2015 Annual Report.

This E-Brief is a publication of the C.D. Howe Institute.

Steven Robins is a joint MBA and Master Public Policy Candidate at Harvard University.

This E-Brief is available at www.cdhowe.org.

Permission is granted to reprint this text if the content is not altered and proper attribution is provided. 